\title{
ANALYSIS OF PHYSICO CHEMICAL PARAMETERS IN NEYYAR RIVER WITH SPECIAL REFERENCE TO ENVIRONMENTAL POLLUTION
}

\author{
BADUSHA .M ${ }^{1} \&$ SANTHOSH. $\mathrm{S}^{2}$ \\ ${ }^{1}$ Department of Zoology, N.S.S. College, Pandalam, Kerala, India \\ ${ }^{2}$ Department of Zoology, N.S.S. College, Pandalam, Kerala, India
}

\begin{abstract}
Neyyar is the southern most river of Kerala state. This river having a length of 56 Km is now facing serious environmental fall out due to various anthropogenic activities. This paper reveals the seasonal fluctuations in various physico-chemical parameters in Neyyar River based on the investigations done from May 2015 to April-2016. Six sampling sites, namely Neyyar Dam, Kallikkadu, Mandapathinkadavu, Aruvippuram, Neyyattinkara and Poovarwer were selected depending upon the various pollution sources. In this study, minimum pollution was reported at the Neyyar dam, which is located near the river origin and maximum pollution at the Poovar, which is located near Pozhikkara.

KEYWORDS: Neyyar, Physico-Chemical Parameters \& Pollution
\end{abstract}

Received: Jan 02, 2018; Accepted: Jan 22, 2018; Published: Feb 13, 2018; Paper Id.: IJEEFUSFEB20183

\section{INTRODUCTION}

Neyyar River is one of the important small catchment rivers in the south-western coast of India, originates from Agasthyamalai in the Western Ghat mountain ranges at an elevation of about $1866 \mathrm{Km}$ above mean sea level. This small river flows through highly varied geologic and physiographic provinces of the area for a length of about $56 \mathrm{Km}$. This river faces severe pollution threats, because of the huge disposal of various waste materials, sand mining, reclamation of paddy fields, etc., The water related issues are very critical in the small catchment rivers of developing economies with high incidence of human stress (Padmalalet al., 2011). The water quality of a riverine ecosystem can be assessed mostly by studying its physico-chemical characteristics. The seasonal change in surface water quality is an important aspect of evaluating sequential variations of river pollution (Ouyanget al., 2006). Under this context, the present study tries to focus on the water quality changes along the course of Neyyar River from the upstream stretch to the downstream during monsoon and pre-monsoon seasons.

\section{MATERIALS AND METHODS}

Neyyar River is located in Thiruvananthapuram district and is positioned between $8^{\circ} 15^{\prime}$ to $8^{\circ} 40^{\prime}-\mathrm{N}$ latitudes and $77^{\circ} 00^{\prime}$ to $77^{\circ} 20^{\prime}$-E longitudes. Water samples were collected from six sampling stations on the river monthly for two seasons, namely monsoon and pre-monsoon from May 2015 to April 2016. The sampling sites such as Neyyar Dam (S-I), Kallikadu (S-II), Mandapathinkadavu (S-III), Aruvippuram (S-IV), Neyyattinkara (S-V) and Poovar (S-VI) are fixed along the river considering the pollution sources (Figure. 1). The Station I and Station II are situated in the highland physiographies area is with less anthropogenic activities, where as Station III (transection area of highland and midland) and Station IV (midland area) are located in a polluted environment. 
The Station V and Station VI, physiographically lowland in position are with severe pollution activities.

In the present study, the variations in river water sample are analyzed for physico-chemical parameters such as Water temperature (WT), Hydrogen ion concentration (PH), Electrical Conductivity (EC), Total dissolved solids (TDS), Nitrate $\left(\mathrm{NO}_{3}\right)$, Sulphate $\left(\mathrm{SO}_{4}\right)$, Dissolved oxygen (DO) and Biological oxygen demand (BOD). In-situ determination is done for parameters such as Water temperature and PH and samples of DO and BOD is chemically fixed in the field itself. All the parameters were measured by standard analytical methods(APHA, 2012). The significance of the result was statistically verified by two way anova and correlation using SPSS package 16.00.

\section{RESULTS AND DISCUSSIONS}

In Neyyar, River basin pollution sources are comparatively less in Station I. This might be due to less agglomerated settlement on the reclaimed wetlands. The sampling location at Kallikadu is almost stagnant due to the extensive sand mining underwent earlier. Highland of a river basin is more sensitive since it has unique biodiversity and abundant surface and groundwater resources. Any activity that destructs the area will not only affect its ecosystem, but also damage the sustainable ecosystem of the midland and lowland area of the basin. Drainage carrying sewage from a microwatershed settlement is directly debouching into the river site at Mandapathinkadavu. Unscientific construction of bunds across the river and intense paddy reclamation are common in Aruvippuram. Due to increase in population density, the sampling site at Neyyattinkara is grossly polluted with municipal, chemical and domestic wastes. Power is located near the Coast of Lakshadweep Sea, where the river water is stagnant and highly polluted. All pollutants from upstream are concentrated in this region. Estuarine influence was also visible in this region. These factors can affect the hydrological conditions of respective sampling sites in the present study area. Seasonal variations can also affect the hydrology of any water body. The impact of all these changes is reflected in the physico chemical distribution of river water. The seasonal variations in the water quality parameters of the six sampling sites have summarized in Table 1.

The present study indicates that the fluctuation in water temperature has a relative influence of rainfall. Water temperature showed a decrease in trend during monsoon. A considerable decrease in water temperature at the stations located in the high land area (S I \& S II) may be due to the influence of sampling time in the early morning hours. Two way anova showed significant difference in water temperature between sites $(\mathrm{F}>\mathrm{F}$ crit, $\mathrm{P}=0.001)$ and between seasons $(\mathrm{F}>\mathrm{F}$ crit, $\mathrm{P}=0.000$ ) (Table 2). The minimum value of $\mathrm{PH}$ is observed at the reservoir during monsoon and the maximum at Poovar in pre-monsoon. Though, seasonal influence was marginal, a lowering in $\mathrm{pH}$ was generally visible during monsoon. The $\mathrm{pH}$ is of near neutral to alkaline range, suggesting well buffered river waters. Two way anova showed significant difference in $\mathrm{PH}$ between sites $(\mathrm{F}>\mathrm{F}$ crit, $\mathrm{P}=0.001)$ and between seasons $(\mathrm{F}>\mathrm{F}$ crit, $\mathrm{P}=0.000)$ (Table 3 ).

Electrical conductivity of water also shows a marginal influence of rain. In the station near Pozhikkara (S VI), the intrusion of sea water resulted in the enhancement EC and TDS far above the limit prescribed by BIS (2004). Not only that, its increase towards downstream could be due to the urban and agricultural drainage and various ions added to the water from catchment areas. Two way anova showed significant difference in electrical conductivity between sites ( $\mathrm{F}>\mathrm{F}$ crit, $\mathrm{P}=0.000)$ and no significant difference observed between seasons ( $\mathrm{F}<\mathrm{F}$ crit, $\mathrm{P}=0.344)$ (Table 4). TDS follows the trend of EC in all seasons, as TDS is directly proportional to EC. The minimum value of TDS observed in the reservoir during monsoon and maximum value was observed in the Poovar during pre-monsoon. Two way anova showed significant difference in TDS between sites $(\mathrm{F}>\mathrm{F}$ crit, $\mathrm{P}=0.001)$ and no significant difference observed between seasons $(\mathrm{F}<\mathrm{F}$ crit, $\mathrm{P}=0.355)$ (Table 5). 
Though, Nitrate was negligible in all seasons in the upstream stations, samples in the mid and lowland invariably showed considerable concentrations of this nutrient. High values of nitrate during the rainy season can be due to an influx of nitrogen rich flood water that brings large amount of contaminated sewage water. Two way anova showed significant difference in $\mathrm{NO}_{3}$ between sites $(\mathrm{F}>\mathrm{F}$ crit, $\mathrm{P}=0.000)$ and no significant difference observed between seasons $(\mathrm{F}<\mathrm{F}$ crit, $\mathrm{P}=0.963$ ) (Table 6). The concentration of sulphate was found to be very low up to Aruvippuram, from where it increased maximum at Poovar, which is very close to the sea. Two way anova showed significant difference in $\mathrm{PO}_{4}$ between sites $(\mathrm{F}>\mathrm{F}$ crit, $\mathrm{P}=0.002)$ and no significant difference observed between seasons $(\mathrm{F}<\mathrm{F}$ crit, $\mathrm{P}=0.318)($ Table 7$)$

The DO values recorded minimum during pre-monsoon at Neyyattinkara and Poovar and maximum during monsoon at Aruvippuram. The higher concentration of DO during winter can be attributed to the fact that cold water contains more oxygen as compared to warm water as the DO is inversely proportional to the water temperature (Hynes, 1988). In addition photosynthesis could have some kind of effect on DO. Two way anova showed significant difference in water temperature between sites $(\mathrm{F}>\mathrm{F}$ crit, $\mathrm{P}=0.001)$ and between seasons $(\mathrm{F}>\mathrm{F}$ crit, $\mathrm{P}=0.004)$ (Table 8). Inverse to the distribution of DO, the BOD values fluctuates between the lowest in reservoir during monsoon to the highest in Neyyattinkara and Poovar during premonsoon. The BOD values are obtained maximum in pre-monsoon at all sampling stations, which may be due to high temperature, this in turn promotes microbial activities and minimum BOD values obtained during monsoon may be due to low temperature and sufficient amount of water in the river. Similar observations were confirmed by many other workers such as Pathak and Mudgal (2005). Two way anova showed significant difference in water temperature between sites $(\mathrm{F}>\mathrm{F}$ crit, $\mathrm{P}=0.000)$ and between seasons $(\mathrm{F}>\mathrm{F}$ crit, $\mathrm{P}=0.000)$ (Table 9). Most of the parameters of water samples at Poovar station exceeded the permissible limit prescribed by BIS (2004). Dissolved oxygen from all the stations is below the limit prescribed by BIS (2004), which clearly indicate the oxygen demanding wastes prevalent in the present study area.

Correlation coefficient analysis of the water quality parameters demonstrates clearly the type and degree of relationship among them. Correlation between the parameters during monsoon and premonsoon is shown in Table 10 and Table 11 respectively. In monsoon, water temperature showed significant positive correlation at $1 \%$ level with $\mathrm{NO}_{3}$ $(\mathrm{r}=0.966)$ and at 5\% level with BOD $(\mathrm{r}=0.869)$. PH showed significant positive correlation at 5\% level with EC ( $\mathrm{r}=0.909)$, TDS (r=0.909) and $\mathrm{SO}_{4}(\mathrm{r}=0.914)$. EC showed significant positive correlation at $1 \%$ level with $\mathrm{TDS}_{(\mathrm{r}=1.000)}$ and $\mathrm{SO}_{4}$ $(\mathrm{r}=1.000)$. TDS showed significant positive correlation at $1 \%$ level with $\mathrm{SO}_{4}(\mathrm{r}=1.000)$. Nitrate showed significant positive correlation at $5 \%$ level with BOD $(r=0.866)$. Dissolved oxygen showed negative correlation with all parameters. In premonsoon water temperature showed significant positive correlation at $1 \%$ level with BOD (r=0.935) and at 5\% level with $\mathrm{PH}(\mathrm{r}=0.848)$ and $\mathrm{NO}_{3}$ (0.890). PH showed significant positive correlation at 5\% level with EC ( $\left.\mathrm{r}=0.894\right)$, TDS (r=0.895), $\mathrm{SO}_{4}(\mathrm{r}=0.902)$ and BOD $(\mathrm{r}=0.836)$. EC showed correlation pattern similar to that observed in monsoon with $\mathrm{TDS}_{\text {and }} \mathrm{SO}_{4}$. TDS also showed correlation pattern similar to that observed in monsoon with $\mathrm{SO}_{4}$. Nitrate showed significant positive correlation at $1 \%$ level with BOD $(\mathrm{r}=0.940)$. Dissolved oxygen showed negative correlation with all parameters in premonsoon also.

\section{CONCLUSIONS}

- The Neyyar River, which acts as the southern most river of Kerala is in the verge of destruction due to various environmental problems.

- The degradation of water quality is very high at the down stream stretches of the river especially at Neyyattinkara 
and Poovar. This is due to high anthropogenic disturbances associated with the region, the cumulative effect of all pollutants from up stream and the influence of sea water.

- The water quality parameters such as Water Temperature, PH, Electrical Conductivity, Total Dissolved Solids, Sulphate and Biological Oxygen Demand are comparatively high in pre-monsoon season, where as the Nitrate and Dissolved Oxygen are high during monsoon.

- So this study pointing towards the need for control measures to protect the river from severe pollution threats and thereby maintain a good quality water for the need of human beings as well as other organisms connected with this ecosystem.

\section{ACKNOWLEDGEMENTS}

We are indebted to University of Kerala for the financial assistance. The facilities provided by Research Department of Zoology, NSS College, Pandalam are immeasurably acknowledged.

\section{REFERENCES}

1. APHA. (2012). Standard methods for the examination of water and waste water (22 ${ }^{\text {nd }}$ ed.), (pp.1175). American Public Health Association, Washington DC.

2. Bureau of Indian Standards, Indian Standards (IS: 10500). (2004). Drinking Water Specification, New Delhi.

3. Hynes. H.B.N. (1988). Biogeography and origins of the North American Stone flies (Plecoptera). Mem. Ent. Soc. Can, 44:3137.

4. Ouyang. Y, Nkedi-Kizza. P, Wu. Q.T, Shinde. D, Huang. C.H. (2006). Assessment of seasonal variations in surface water quality. Water Res, 40:3800-3810.

5. Padmalal. D, Remya. S.I, Jyothi. S.J, Baijulal. B, Babu. K.N, Baiju. R.S. (2011). Water Quality and Dissolved Inorganic Fluxes of N, P, SO4and K of a Small Catchment River in the Southwestern Coast of India. Environ. Monit. Assess, 84:15411557.

6. Pathak. S.K, Mudgal. L.K. (2004). Biodiversity of zooplankton of Virla reservoir, Khargone (M.P.), India, In: Arvind Kumar (ed.) Biodiversity and Environment, (pp.317-321).New Delhi: A.P.H. Publishing Corporation.

\section{TABLES}

Table 1: Season Wise Variations of Water Quality Parameters of Neyyar River

\begin{tabular}{|c|c|c|c|c|c|c|c|c|c|c|c|c|c|}
\hline \multirow[t]{2}{*}{ Parameters } & \multicolumn{6}{|c|}{ Monsoon } & \multicolumn{6}{|c|}{ Pre-monsoon } & \multirow[t]{2}{*}{ BIS } \\
\hline & S-1 & S-II & S-III & S-IV & S-V & S-VI & S-I & s-iा & S-III & S-IV & S.V & S-VI & \\
\hline WT $\left({ }^{\circ} \mathrm{C}\right)$ & 27.2 & 27.2 & 27.7 & 28.2 & 29.5 & 30.2 & 30.5 & 30.8 & 31.5 & 31.8 & 32.7 & 32.8 & …. \\
\hline PH & 6.6 & 6.8 & 6.8 & 6.9 & 6.8 & 7.3 & 6.9 & 7.1 & 7.2 & 7.2 & 7.3 & 7.8 & $6.5-8.5$ \\
\hline $\mathrm{EC}(\mu \mathrm{s} / \mathrm{cm})$ & 30.4 & 45.7 & 52.8 & 58.0 & 66.3 & 7533.5 & 44.7 & 57.9 & 61.1 & 61.5 & 76.5 & 8856.8 & 1500 \\
\hline TDS(mg/l) & 20.5 & 31.4 & 34.5 & 40.1 & 46.4 & 4699.3 & 27.2 & 40.5 & 41.2 & 44.5 & 53.5 & 6933.4 & 500 \\
\hline Nitrate(mg/l) & 0.3 & 0.3 & 0.4 & 0.4 & 1.9 & 2.5 & 0.2 & 0.3 & 0.4 & 0.3 & 2.2 & 2.3 & 45 \\
\hline Sulphate $(\mathrm{mg} / \mathrm{l})$ & 0.9 & 2.3 & 2.8 & 2.2 & 4.0 & 98.8 & 1.3 & 3.5 & 3.9 & 3.0 & 5.3 & 152.8 & 200 \\
\hline DO(mg/) & 5.7 & 4.7 & 5.0 & 5.8 & 4.5 & 4.4 & 5.2 & 4.4 & 4.5 & 5.1 & 4.2 & 4.2 & 6 \\
\hline BOD $(\mathrm{mg} / \mathrm{l})$ & 0.4 & 2.3 & 2.7 & 1.9 & 4.6 & 4.5 & 1.9 & 2.9 & 3.7 & 2.9 & 5.4 & 5.4 & 3 \\
\hline
\end{tabular}


Table 2: Anova Showing the Significance of Variation in WT in Monsoon and Premonsoon

\begin{tabular}{llllllllllll}
\hline Sites & Monsoon & Premonsoon & Mean \pm SD & $\begin{array}{l}\text { Source of } \\
\text { Variation }\end{array}$ & SS & df & MS & $\boldsymbol{F}$ & P-value & F crit \\
\hline S-I & 27.2 & 30.5 & $28.9 \pm 2.3$ & Rows & 11.88 & 5 & 2.38 & 25.98 & 0.001 & 5.05 \\
S-II & 27.2 & 30.8 & $29.0 \pm 2.5$ & Columns & 33.67 & 1 & 33.66 & 367.95 & 0.000 & 6.61 \\
S-III & 27.7 & 31.5 & $29.6 \pm 2.7$ & Error & 0.46 & 5 & 0.09 & & & \\
S-IV & 28.2 & 31.8 & $30.0 \pm 2.5$ & Total & 46.01 & 11 & & & & \\
S-V & 29.5 & 32.7 & $31.1 \pm 2.3$ & & & & & & & \\
\hline S-VI & 30.2 & 32.8 & $31.5 \pm 1.8$ & & & & & & & \\
\hline Mean \pm SD & $28.3 \pm 1.3$ & $31.7 \pm 0.9$ & & & & & & & & \\
\hline
\end{tabular}

Table 3: Anova Showing the Significance of Variation in $\mathrm{PH}$ in Monsoon and Premonsoon

\begin{tabular}{|c|c|c|c|c|c|c|c|c|c|c|}
\hline Sites & Monsoon & Premonsoon & Mean \pm SD & $\begin{array}{l}\text { Source } \\
\text { of } \\
\text { Variation }\end{array}$ & $S S$ & $d f$ & $M S$ & $F$ & P-value & $F$ crit \\
\hline S-I & 6.6 & 6.9 & $6.8 \pm 0.2$ & Rows & 0.70 & 5 & 0.14 & 29.14 & 0.001 & 5.05 \\
\hline S-II & 6.8 & 7.1 & $7.0 \pm 0.2$ & Columns & 0.44 & 1 & 0.44 & 91.21 & 0.000 & 6.61 \\
\hline S-III & 6.8 & 7.2 & $7.0 \pm 0.3$ & Error & 0.02 & 5 & 0.00 & & & \\
\hline S-IV & 6.9 & 7.2 & $7.1 \pm 0.2$ & \multirow[t]{4}{*}{ Total } & \multirow[t]{4}{*}{1.17} & \multirow[t]{4}{*}{11} & & & & \\
\hline S-V & 6.8 & 7.3 & $7.1 \pm 0.4$ & & & & & & & \\
\hline S-VI & 7.3 & 7.8 & \multirow[t]{2}{*}{$7.6 \pm 0.4$} & & & & & & & \\
\hline Mean \pm SD & $6.9 \pm 0.2$ & $7.3 \pm 0.3$ & & & & & & & & \\
\hline
\end{tabular}

Table 4: Anova Showing the Significance of Variation in EC in Monsoon and Premonsoon

\begin{tabular}{llllllllllll}
\hline Sites & Monsoon & Premonsoon & Mean \pm SD & $\begin{array}{l}\text { Source } \\
\text { of } \\
\text { Variation }\end{array}$ & & SS & df & MS & F & P-value & F crit \\
\hline S-I & 30.4 & 44.7 & $37.6 \pm 10.1$ & Rows & 110424659.30 & 5 & 22084931.85 & 153.58 & 0.000 & 5.05 \\
\hline S-II & 45.7 & 57.9 & $51.8 \pm 8.6$ & Columns & 156819.60 & 1 & 156819.60 & 1.09 & 0.344 & 6.61 \\
\hline S-III & 52.8 & 61.1 & $57.0 \pm 5.9$ & Error & 719011.09 & 5 & 143802.22 & & & \\
\hline S-IV & 58.0 & 61.5 & $59.8 \pm 2.5$ & Total & 111300490.00 & 11 & & & & & \\
S-V & 66.3 & 76.5 & $71.4 \pm 7.2$ & & & & & & & & \\
\hline S-VI & 7533.5 & 8856.8 & $8195.2 \pm 935.7$ & & & & & & & & \\
\hline Mean \pm SD & $1297.8 \pm 3054.9$ & $1526.4 \pm 3591.2$ & & & & & & & & & \\
\hline
\end{tabular}

Table.5: Anova Showing the Significance of Variation in TDS in Monsoon and Premonsoon

\begin{tabular}{|c|c|c|c|c|c|c|c|c|c|c|}
\hline Sites & Monsoon & Premonsoon & Mean \pm SD & $\begin{array}{l}\text { Source } \\
\text { of } \\
\text { Variation }\end{array}$ & $S S$ & $d f$ & $M S$ & $F$ & P-value & F crit \\
\hline S-I & 20.5 & 27.2 & $23.9 \pm 4.7$ & Rows & 55649998.00 & 5 & 11130000.00 & 26.92 & 0.001 & 5.05 \\
\hline S-II & 31.4 & 40.5 & $36.0 \pm 6.4$ & Columns & 428689.80 & 1 & 428689.80 & \multirow[t]{6}{*}{1.04} & 0.355 & \multirow[t]{6}{*}{6.61} \\
\hline S-III & 34.5 & 41.2 & $37.9 \pm 4.7$ & Error & 2067033.00 & 5 & 413406.60 & & & \\
\hline S-IV & 40.1 & 44.5 & $42.3 \pm 3.1$ & \multirow[t]{4}{*}{ Total } & \multirow[t]{4}{*}{58145720.00} & \multirow[t]{4}{*}{11} & & & & \\
\hline S-V & 46.4 & 53.5 & $50.0 \pm 5.0$ & & & & & & & \\
\hline S-VI & 4699.3 & 6933.4 & $5816.4 \pm 1579.7$ & & & & & & & \\
\hline Mean \pm SD & $812.0 \pm 1904.4$ & $1190.1 \pm 2813.7$ & & & & & & & & \\
\hline
\end{tabular}

Table.6: Anova Showing the Significance of Variation in $\mathrm{NO}_{3}$ in Monsoon and Premonsoon

\begin{tabular}{|c|c|c|c|c|c|c|c|c|c|c|}
\hline Sites & Monsoon & Premonsoon & Mean \pm SD & $\begin{array}{l}\text { Source } \\
\text { of } \\
\text { Variation }\end{array}$ & SS & $d f$ & $M S$ & $F$ & $P$-value & F crit \\
\hline S-I & 0.3 & 0.2 & $0.2 \pm 0.05$ & Rows & 9.89 & 5 & 1.98 & 141.83 & 0.000 & 5.05 \\
\hline S-II & 0.3 & 0.3 & $0.3 \pm 0.02$ & Columns & 0.00 & 1 & 0.00 & 0.002 & 0.963 & 6.61 \\
\hline S-III & 0.4 & 0.4 & $0.4 \pm 0.01$ & Error & 0.07 & 5 & 0.01 & & & \\
\hline S-IV & 0.4 & 0.3 & $0.3 \pm 0.05$ & Total & 9.97 & 11 & & & & \\
\hline S-V & 1.9 & 2.2 & $2.1 \pm 0.22$ & & & & & & & \\
\hline S-VI & 2.5 & 2.3 & $2.4 \pm 0.13$ & & & & & & & \\
\hline Mean \pm SD & $1.0 \pm 1.0$ & $1.0 \pm 1.0$ & & & & & & & & \\
\hline
\end{tabular}


Table.7: Anova Showing the Significance of Variation in $\mathrm{PO}_{4}$ in Monsoon and Premonsoon

\begin{tabular}{|c|c|c|c|c|c|c|c|c|c|c|}
\hline Sites & Monsoon & Premonsoon & Mean \pm SD & $\begin{array}{l}\text { Source } \\
\text { of } \\
\text { Variation }\end{array}$ & $S S$ & $d f$ & $M S$ & $F$ & P-value & $F$ crit \\
\hline S-I & 0.9 & 1.3 & $1.1 \pm 0.3$ & Rows & 25198.80 & 5 & 5039.75 & 21.49 & 0.002 & 5.05 \\
\hline S-II & 2.3 & 3.5 & $2.9 \pm 0.9$ & Columns & 288.71 & 1 & 288.71 & 1.23 & 0.318 & 6.61 \\
\hline S-III & 2.8 & 3.9 & $3.4 \pm 0.8$ & Error & 1172.47 & 5 & 234.49 & & & \\
\hline S-IV & 2.2 & 3.0 & $2.6 \pm 0.5$ & \multirow[t]{4}{*}{ Total } & \multirow[t]{4}{*}{26659.90} & \multirow[t]{4}{*}{11} & & & & \\
\hline S-V & 4.0 & 5.3 & $4.6 \pm 0.9$ & & & & & & & \\
\hline S-VI & 98.8 & 152.8 & $125.8 \pm 38.2$ & & & & & & & \\
\hline Mean \pm SD & $18.5 \pm 39.4$ & $28.3 \pm 61.0$ & & & & & & & & \\
\hline
\end{tabular}

Table.8: Anova Showing the Significance of Variation in DO in Monsoon and Premonsoon

\begin{tabular}{|c|c|c|c|c|c|c|c|c|c|c|}
\hline Sites & Monsoon & Premonsoon & Mean \pm SD & $\begin{array}{l}\text { Source } \\
\text { of } \\
\text { Variation }\end{array}$ & $S S$ & $d f$ & $M S$ & $F$ & P-value & F crit \\
\hline S-I & 5.7 & 5.2 & $5.4 \pm 0.3$ & Rows & 2.87 & 5 & 0.57 & 28.70 & 0.001 & 5.05 \\
\hline S-II & 4.7 & 4.4 & $4.5 \pm 0.2$ & Columns & 0.49 & 1 & 0.49 & 24.63 & 0.004 & 6.61 \\
\hline S-III & 5.0 & 4.5 & $4.7 \pm 0.3$ & Error & 0.10 & 5 & 0.02 & & & \\
\hline S-IV & 5.8 & 5.1 & $5.5 \pm 0.5$ & Total & 3.46 & 11 & & & & \\
\hline S-V & 4.5 & 4.2 & $4.3 \pm 0.2$ & & & & & & & \\
\hline S-VI & 4.4 & 4.2 & $4.3 \pm 0.1$ & & & & & & & \\
\hline Mean \pm SD & $5.0 \pm 0.6$ & $4.6 \pm 0.5$ & & & & & & & & \\
\hline
\end{tabular}

Table.9: Anova Showing the Significance of Variation in BOD in Monsoon and Premonsoon

\begin{tabular}{|c|c|c|c|c|c|c|c|c|c|c|}
\hline Sites & Monsoon & Premonsoon & Mean \pm SD & $\begin{array}{l}\text { Source } \\
\text { of } \\
\text { Variation }\end{array}$ & $S S$ & $d f$ & $M S$ & $F$ & P-value & F crit \\
\hline S-I & 0.4 & 1.9 & $1.1 \pm 1.1$ & Rows & 23.14 & 5 & 4.63 & 117.91 & 0.000 & 5.05 \\
\hline S-II & 2.3 & 2.9 & $2.6 \pm 0.5$ & Columns & 2.87 & 1 & 2.87 & 73.16 & 0.000 & 6.61 \\
\hline S-III & 2.7 & 3.7 & $3.2 \pm 0.7$ & Error & 0.20 & 5 & 0.04 & & & \\
\hline S-IV & 1.9 & 2.9 & $2.4 \pm 0.7$ & Total & 26.21 & 11 & & & & \\
\hline S-V & 4.6 & 5.4 & $5.0 \pm 0.6$ & & & & & & & \\
\hline S-VI & 4.5 & 5.4 & $4.9 \pm 0.6$ & & & & & & & \\
\hline Mean \pm SD & $2.7 \pm 1.6$ & $3.7 \pm 1.4$ & & & & & & & & \\
\hline
\end{tabular}

Table.10: Correlation Between Water Quality

Parameters of Neyyar in Monsoon

\begin{tabular}{|l|r|r|r|r|r|r|r|r|}
\hline & \multicolumn{1}{|c|}{ WT } & \multicolumn{1}{c|}{ PH } & \multicolumn{1}{c|}{ EC } & \multicolumn{1}{c|}{ TDS } & \multicolumn{1}{c|}{ NO3 } & \multicolumn{1}{c|}{ SO4 } & DO & BOD \\
\hline WT & 1 & & & & & & & \\
\hline PH & 0.784 & 1 & & & & & & \\
\hline EC & 0.733 & $0.909^{*}$ & 1 & & & & & \\
\hline TDS & 0.733 & $0.909^{*}$ & $1.000^{* *}$ & 1 & & & & \\
\hline NO3 & $0.966^{* *}$ & 0.740 & 0.772 & 0.773 & 1 & & & \\
\hline SO4 & 0.745 & $0.914^{*}$ & $1.000^{* *}$ & $1.000^{* *}$ & 0.783 & & & \\
\hline DO & -0.598 & -0.519 & -0.501 & -0.501 & -0.715 & -0.516 & 1 & \\
\hline BOD & $0.869^{*}$ & 0.674 & 0.541 & 0.542 & $0.866^{*}$ & 0.559 & $-0.856^{*}$ & 1 \\
\hline
\end{tabular}

$* *$ Correlation is significant at the 0.01 level (2-tailed).

* Correlation is significant at the 0.05 level (2-tailed). 
Table.11: Correlation Between Water Quality

Parameters of Neyyar in Premonsoon

\begin{tabular}{|l|r|r|r|r|r|r|r|r|}
\hline & \multicolumn{1}{|c|}{ WT } & \multicolumn{1}{c|}{ PH } & \multicolumn{1}{c|}{ EC } & \multicolumn{1}{c|}{ TDS } & \multicolumn{1}{c|}{ NO3 } & \multicolumn{1}{c|}{ SO4 } & DO & BOD \\
\hline WT & 1 & & & & & & & \\
\hline PH & $0.848^{*}$ & 1 & & & & & & \\
\hline EC & 0.578 & $0.894^{*}$ & 1 & & & & & \\
\hline TDS & 0.578 & $0.895^{*}$ & $1.000^{* *}$ & 1 & & & & \\
\hline NO3 & $0.890^{*}$ & 0.805 & 0.657 & 0.657 & 1 & & & \\
\hline SO4 & 0.590 & $0.902^{*}$ & $1.000^{* *}$ & $1.000^{* *}$ & 0.668 & & & \\
\hline DO & -0.623 & -0.659 & -0.444 & -0.444 & -0.729 & -0.459 & 1 & \\
\hline BOD & $0.935^{* *}$ & $0.836^{*}$ & 0.582 & 0.582 & $0.940^{* *}$ & 0.597 & $-0.844^{*}$ & 1 \\
\hline
\end{tabular}

*Correlation is significant at the 0.05 level (2-tailed).

$* *$ Correlation is significant at the 0.01 level (2-tailed).

\section{FIGURES}

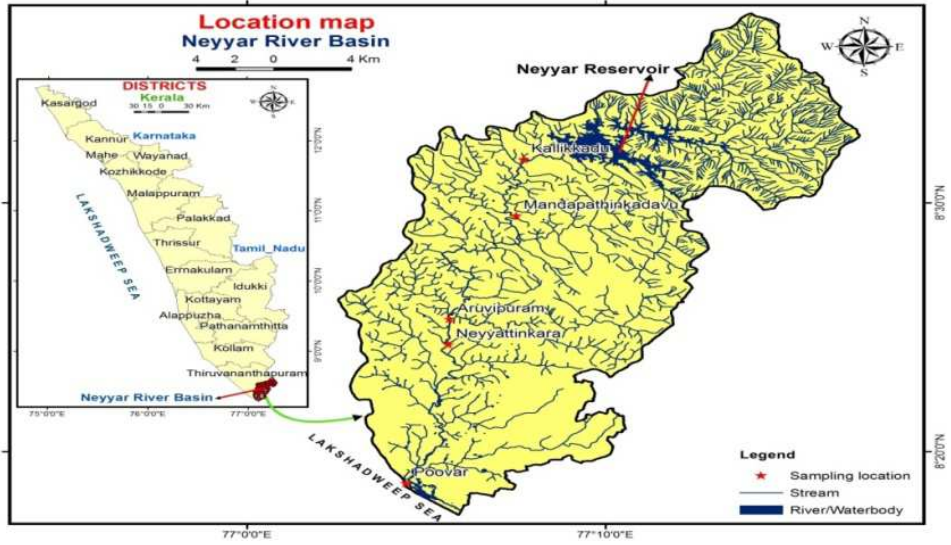

Figure.1: Water Sampling Locations in Neyyar River 
